() С. Б. Фіялка, к.н.с.к., КПІ ім. Ігоря Сікорського, Київ, Україна

\title{
ВІДЕОІГРИ ЯК ІНСТРУМЕНТ ПРОПАГАНДИ В УМОВАХ РОСІЙСЬКО-УКРАЇНСЬКОГО ПРОТИСТОЯННЯ
}

Досліджено пропагандистські мотиви у відеоіграх, побудованих на сюжетах українсько-російського протистояння. У відеоіграх виявлено такі методи пропаганди: багатократне повторення певної ідеї, використання емоційних висловлювань, демонізація ворога, фальсифікація історії, спекулювання на ідеях патріотизму, навішування ярликів, культивування стереотипів. При цьому в іграх нав'язуються ті самі наративи, що поширюються антиукраїнськими мас-медіа, а також простежується застосування подвійних стандартів. Як джерело пропаганди розробники відеоігор за мотивами російсько-українського протистояння використовують три напрями переконування: за допомогою слів, образів та операцій (геймплею). Щоб уникнути деструктивного пропагандистського впливу відеоігор на українську громадськість, потрібно відстежувати їхній зміст: чи не спотворюють вони геополітичного становища України, чи не завдають шкоди іміджу нашої держави. Водночас на рівні держави потрібно заохочувати створення ігрових продуктів із закладеними в них національними цінностями, наступальною історичною пропагандою.

Ключові слова: відеогра; пропаганда; риторика ворожнечі; маніпуляція; демонізація ворога; фальсифікація історії.

Постановка проблеми

В умовах російської воєнної агресії антиукраїнська пропаганда з політичної та журналістської площин активно проникає також у літературу, музику, кіномистецтво та інші галузі культури. З розвитком цифрового ринкупроводиться вона, зокрема, і через таку форму масового мистецтва, як відеоігри, метою яких стає спотворення української історії, дискредитація внутрішньої та зовнішньої політики нашої дер- жави, формування негативного образу України як серед іноземців, так і поміж самих українців, а також підвищення порога терпимості до агресії серед гравців, закріплення образів з ігор у їхній свідомості. Такі ігри не тільки поширюють певні меседжі, а й створюють ілюзію активної діяльності: долучають гравців до процесу прийняття рішень, дозволяють їм стати віртуальними учасниками бойових сутичок, стають форумами, які надають нічим не обмежену

(ㄷ) $2017 \mathrm{p}$. 
можливість висловлювати думки щодо воєнного конфлікту. При цьому відеоігри пропонують альтернативні версії розвитку подій, що «можуть вбудовуватися у свідомість гравців» [1]. Інакше кажучи, відеоігри мають величезний потенціал формування позицій гравців і «здатні впливати на їхню поведінку такими методами, про які Геббельс навіть не міг мріяти» [2]. Тож актуальність дослідження контенту відеоігор, що виникають на тлі воєнно-політичного протистояння, з'ясування їхнього пропагандистського впливу можна вважати беззаперечною.

\section{Аналіз попередніх досліджень}

Науковці визначають пропаганду як комунікаційну технологію, покликану впливати на думки і поведінку людей 3 метою отримання від об'єктів впливу відгуку, який відповідає меті пропагандиста [3]. Пропаганда передбачає наявність ідеї, цільової аудиторії та засобів, щоб донести цю ідею до цільової аудиторіï.

Останнім часом спостерігається зростання наукового інтересу до того, як масова культура і розважальні медіа репрезентують воєнні конфлікти 3 використанням пропаганди [4-6]. Зокрема, дедалі більшу увагу науковці приділяють відеоіграм: вони окреслили їхню роль у гарантуванні міжнародної безпеки, виявили, чим відеоігри відрізняються від інших медіа, а також дослідили потенціал відеоігор як джерела пропаганди [7-12].

Серед ознак відеоігор виокремлюють інтерактивність, роз- митість меж між творцем контенту та його споживачем, добровільну участь, змагальність, ідею перемоги, наявність мети, правил, нагород [13]. При цьому відеоігри, які базуються на конфліктах, здатні конструювати «суспільну пам'ять» [14].

\section{Мета роботи}

Виявити пропагандистські мотиви у відеоіграх, побудованих на сюжетах українсько-російського протистояння.

\section{Результати проведених досліджень}

На хвилі бурхливого розвитку інформаційно-комунікаційних технологій ігрові сервіси пропонуються 3 різних платформ: персонального комп'ютера, телевізійної приставки, мобільного телефона, ігрових автоматів. Для дослідження ми відібрали наявні на Google Play відеоігри, які так чи інакше зачіпають постмайданні події в Україні. Це як ігри, створені патріотично налаштованими українськими розробниками, так і проросійські ігри, що культивують імперські амбіції Російської Федерації.

Спершу розглянемо приклади відеоігор з проросійською риторикою. Так, у грі «Імперія» пропонується стати правителем великої Російської імперії й вести її «до великих перемог». Складається гра 3 кампаній сюжетних ліній: «Битва за Москву», «Микола II», «Петро |», «Сталін», «Примус до Миру 2008», «Крим наш», «Атака мерців», «Оборона фортеці Осовець», «Кольорова революція», «Перебудова», «Путін» тощо. Регулярно виходять нові кампанії. Гра 
дозволяє керувати державними структурами в різних історичних епохах, побувати в ролі Петра I, Сталіна, Горбачова і навіть Путіна, перемагати у війнах, урятувати СРСР, повернути Аляску, захоплювати нові території. Аудиторія «Імперії» доволі значна: за даними Google Play, ïi встановило понад 100000 користувачів.

Учасники гри можуть відвідати співтовариство гри, вступити до спільноти в соціальній мережі «ВКонтакті», установити стікери в Телеграмі. Прикметно, що фінансовою опорою для створення гри стало «народне фінансування», а вік гравців в описі на Google Play - від трьох років, хоча самі творці позиціюють гру як призначену для аудиторії 16 і старше.

Розробники гарантують «максимальну достовірність і об'єктивність», однак у грі активно спотворюється історична правда й сучасна геополітична картина світу. Так, відповідно до «історичної довідки» до кампанії «Крим наш», обстановка в сусідній Україні невпинно погіршується. Нібито підтримувані західними країнами провокатори та лідери Майдану збираються здійснити незаконний державний переворот, захопивши владу в країні. Усіх опозиційно налаштованих «фашистська хунта» та їі прихильники планують знищити чи змусити коритися. При цьому народ Криму майже в повному складі відмовив у довірі «незаконно встановлюваному режиму», тим самим «наражаючи себе на смертельну небезпеку». Гравці покликані захистити громадян, які не бажають жити «під п'ятою нацистської диктатури та тиранії» й дістають можливість оголосити війну Україні, збільшувати військовий потенціал армії, відправити війська на кордон з Прибалтикою, знизити прожитковий мінімум для стабілізації бюджету, запропонувати українським медіа сюжет про згубність євроінтеграції, віддати наказ охороняти пам'ятки «спільної історії» (наприклад, Леніну), керувати діями ФСБ. Через усю кампанію проходить твердження, що реакція Росії у вигляді анексії Криму - емоційна і спонтанна, нібито зумовлена глибоким відчаєм від подій, які відбувалися в Україні на початку 2014 року.

В ігровій кампанії «Кольорова революція», присвяченій пам'яті громадян, «по звірячому вбитих в одеському Будинку профспілок», пропонується «врятувати Батьківщину» від «коричневої опозиційної чуми, громадянської війни та знищення». Як бачимо, розробники активно послуговуються риторикою ворожнечі й демонізують ворога. Окрім того, викликає питання семантика використовуваного росіянами поняття «Батьківщина».

ще одна антиукраїнська відеогра - «Майдан.Ru». У ній Україна зображається як полігон громадянської війни, країна, де немає ані президента, ані Верховної Ради, ані уряду, а натомість панують хаос та анархія. Перше, що бачить заареєстрований гравець: майдан і попередження «Оставь надежду, всяк сюда входящий». Гравцям пропонується побудувати військову базу, протистояти військам НАТО, об'єднуватися з іншими гравцями в стратегічні альянси й політичні 
союзи. Під командуванням гравця перебувають бойові загони сотні. Учасники гри не просто змагаються - вони боряться за контроль території України, її областей. На базі гри створено власний чат і соціальну мережу гравців, де $є$ друзі, коментарі й особисті блоги. Гру встановило понад 10000 користувачів, вікова категорія не вказана.

Негативні образи України і українців у зазначених відеоіграх $€$ результатом впливу пропаганди в медіа, а також наслідком «патріотичних» намірів розробників. Формуючи образ ворога, антиукраїнські ігри використовуються для виправдання воєнних дій. Звертаючись до кращого в людях - до співчуття та бажання захистити слабких, «своїх», ігри згуртовують населення навколо влади, спонукають його підтримувати імперську політику Російської Федерації, легітимізують воєнні дії російських військ на українській території. Розробники вказаних ігор апелюють до масової свідомості, до архетипів, до колективного «ми», при цьому гравцям пропонується звужена, обмежена віртуальна реальність. Такі ігри порушують норми українського законодавства, підтримуючи порушення територіальної цілісності України та пропагуючи національну ворожнечу.

Проаналізувавши контент антиукраїнських відеоігор, можемо виокремити такі використовувані в них методи пропаганди: багатократне повторення певної ідеї, використання емоційних висловлювань, демонізація ворога, фальсифікація історії, спекулювання на ідеях патріотизму, навішування ярликів, культивування стереотипів. При цьому в іграх нав'язуються ті самі наративи, що культивуються антиукраїнськими мас-медіа, а також простежується застосування подвійних стандартів: «якщо ігри за мотивами російсько-українського протистояння зроблено в Росії, то це патріотизм, інформування та просвіта, але якщо щось подібне роблять українці, то це пропаганда і фашизм».

ще одна гра - «Битва за Донецьк» від бельгійської студії LuGus Studios містить «антивоєнний посил». Кількість установок - понад 100000, вікова категорія - 12 років і старше. Гравець може вибирати сторону, за яку боротиметься, між Україною й так званою «ДНР». Однак, на який би бік не пристав гравець, він все одно програє. Після завершення битви на екран виводяться цифри, скільки мирних мешканців загинуло під час битви. Прикметно, що і ця «антивоєнна гра» опосередковано просуває російські політичні інтереси, адже стороною конфлікту з Україною показана саме ДНР, а не Російська Федерація, яка підтримує бойовиків військами, а також матеріальними та інформаційними ресурсами. Відтак середньостатистичний європеєць, на якого розрахована гра, уводиться в оману щодо того, нібито в Україні йде громадянська війна. Тож тут очевидна підміна понять і маніпуляція.

Натомість серед створених в Україні ігор немає стратегій на кшталт «Імперії», зазвичай у них пропонується або прогнати окупантів з української землі, або ж висміяти їх. Так, у грі «Defend 
Ukraine» гравцям пропонується стати на допомогу українській армії та захистити українські міста від окупантів, запобігти утворенню Новоросії, зберігши цілісність Української держави. При цьому розробники заявляють, що всі доходи від продажу гри йдуть на допомогу українським військовим. Кількість установок гри - понад 1000, вікові обмеження - 12 років і вище.

У грі з елементами гумору «Кримська битва» події розгортаються на Кримському півострові. Гру встановило понад 50000 користувачів, вікова категорія - 3 роки і старше. Баталії відбуваються між рішучими козаками й таємничими інопланетянами. Однак у геймплеї бачимо перевернуте полотно України: жовтий угорі, а блакитний унизу, що стає приводом для насмішок проросійськи налаштованої аудиторії.

В онлайновій грі-шутері «АТО» гравці дістають можливість звільнити Україну від російської окупації, стріляючи в зомбі, що насуваються від східних кордонів держави. Гру встановило понад 10000 користувачів, вікові обмеження - від трьох років.

\section{Висновки}

Російсько-українське воєнне протистояння не залишилося поза увагою творців відеоігор, котрі стали одними із численних бійців інформаційної війни. Відеоігри надають широкі можливості впливу на формування громадської думки, оцінки суспільством політичних, економічних і військових рішень влади. Як джерело пропаганди відеоігри за мотива- ми російсько-українського протистояння використовують три напрями переконування: за допомогою слів, образів та операцій (геймплею). Ігри дають змогу відчути себе повелителем, героєм, господарем ситуації. У них складні проблеми міжнаціональних взаємин зводяться до рівня красивої графіки, при цьому меседж робиться дуже простим, таким, щоб його можна було сприйняти на рівні емоцій. При цьому бездоганно працює повтор: чим більше разів пограв гравець, тим вища можливість відтворення ним породжених грою емоційних реакцій у реальному житті.

Відеоігри посилюють вплив пропаганди і вписують її в публічний дискурс, але водночас і камуфлюють їі. Щоб уникнути деструктивного пропагандистського впливу відеоігор на українську громадськість, потрібно відстежувати їхній зміст: чи не спотворюють вони геополітичного становища України, чи не завдають шкоди іміджу нашої держави. Водночас на рівні держави потрібно заохочувати створення ігрових продуктів із закладеними в них національними цінностями, наступальною історичною пропагандою. Вони можуть стати важливими освітніми інструментами, засобами просування патріотичних ідей та національної історії. При цьому протиставляти проросійській пропаганді в будь-якому разі треба правду, зміщуючи акценти на героїчні сторінки, демонструючи приклади й технології перемоги завдяки розуму й стратегії. 


\section{Список використаної літератури/References}

1. Power, M. (2007). Digitized virtuosity: Video war games and post-9/11 cyber-deterrence. Security Dialogue, 38:2, 271-288 [in English].

2. Delwiche, A. (2007). From the Green Berets to America's army: Video games as a vehicle for political propaganda. The Players' Realm: Studies on the Culture of Video Games and Gaming, McFarland, 92 [in English].

3. The Art of Propaganda: 7 Common Tactics to Influence Behavior. Dosh Dosh. Retrieved October 11, 2017, from www.doshdosh.com [in English].

4. Dodds, K. (2006). Popular geopolitics and audience dispositions: James Bond and the Internet Movie Database (IMDB). Transactions of the Institute of British Geographers, 31:2, 116-130 [in English].

5. Dodds, K. (2008). Hollywood and the popular geopolitics of the War on Terror. Third World Quarterly, 29:8, 1621-1637 [in English].

6. Shapiro, M. (2009). Cinematic Geopolitics. New York, USA: Routledge; Van Veeren, E. (2009). Interrogating 24: Making sense of US Counter-terrorism in the Global War on Terrorism. New Political Science, 31:3, 361-384 [in English].

7. Stahl, R. (2006). Have you played the War on Terror? Critical Studies in Media Communication, 23:2, 112-30 [in English].

8. Höglund, J. (2008). Electronic empire: Orientalism revisited in the military shooter. Game Studies, 8:1. Retrieved October 5, 2017, from http://gamestudies.org/0801/articles/hoeglund [in English].

9. Dyer-Witherford, N. \& de Peuter, G. (2009). Games of Empire: Global Capitalism and Video Games. Minneapolis. USA: University of Minnesota Press [in English].

10. Mirrlees, T. (2009). Digital militainment by design: Producing and playing Socom: U.S. Navy Seals. International Journal of Media \& Cultural Politics, 5:3, 161-181 [in English].

11. Robinson, N. (2012). Videogames, persuasion and the War on Terror: Escaping or embedding the military-entertainment complex? Political Studies, 6:3, 504-522 [in English].

12. Schulzke, M. (2013). The virtual War on Terror: Counterterrorism narratives in video games. New Political Science, 35:4, 586-603 [in English].

13. McGonigal, J. (2011). Reality is broken: why games make us better and how they can change the world. London, 27-28 [in English].

14. Hess, A. (2007). You don't play, you volunteer: Narrative public memory construction in Medal of Honor: Rising Sun. Critical Studies in Media Communication, 24:4, 339-356 [in English].

Исследованы пропагандистские мотивы в видеоиграх, построенных на сюжетах российско-украинского противостояния. В видеоиграх выявлены следующие методы пропаганды: многократное повторение определенной идеи, использование эмоциональных высказываний, демонизация противника, фальсификация истории, спекуляции на идеях патриотизма, навешивание ярлыков, культивирование стереотипов. При этом в играх навязываются нарративы антиукраинских СМИ, а также прослеживается применение двойных стандартов. В качестве источника 
пропаганды в видеоиграх по мотивам российскоукраинского противостояния используются три направления убеждения: с помощью слов, образов и операций (геймплея). Чтобы избежать деструктивного пропагандистского воздействия видеоигр на украинскую общественность, нужно отслеживать их содержание: не искажают ли они геополитического положения Украины, не наносят ли ущерба имиджу государства. В то же время на государственном уровне нужно поощрять создание игровых продуктов с заложенными в них национальными ценностями, наступательной исторической пропагандой.

Ключевые слова: видеоигра; пропаганда; риторика вражды; манипуляция; демонизация противника; фальсификация истории.

The propaganda motives in video games based on plots of Ukrainian-Russian confrontation were explored. For researching we have selected video games available on Google Play dealing with the events occurred in Ukraine after the Revolution of Dignity someway or other. This is the games both created by patriotically-minded Ukrainian developers and pro-Russian ones promoted the imperial ambitions of the Russian Federation. Video games represent the following methods of propaganda: repetition of a certain idea, the use of emotional statements, demonization of the enemy, falsification of history, exploitation the ideas of patriotism, labeling, cultivating stereotypes. Above that, the same narratives that anti-Ukrainian mass media spread are imposed in the games of such kind as well as the double standards are applied. As a source of video game propaganda based on the Russian-Ukrainian confrontation, three ways of persuasions are used: with words, with images and with operations (gameplay). In order to avoid the destructive propaganda impact of video games on the Ukrainian public, it is necessary to monitor their content: if they distort the geopolitical position of Ukraine or harm the image of our state. At the same time, at the state level, it is necessary to encourage the creation of gaming products based on national values, as well as on historical propaganda.

Keywords: videogame; propaganda; aggressive/strife rhetoric; manipulation; demonization of the enemy; falsification of history. 